\title{
Die eise van 'n funksionele kultuur
}

\author{
J LAMPRECHT
}

\section{Inleiding}

Hierdie artikel gaan uit van die standpunt dat elke mens en elke mensprobleem verstaan moet word binne die struktuur van die kultuur waarin dit voorkom. Hierdie standpunt impliseer verder dat die mense van elke kultuur, of breër kultuurtipe, hulle wêreld verstaan slegs binne die raamwerk van 'n synsverstaan wat met daardie kultuur saamhang.

Die kultuur waarin ons vandag lewe, is ' $n$ funksionele kultuur waarin die mens sy wêreld verstaan slegs binne die raamwerk van 'n wetenskaplike synsverstaan.

\section{Kultuurfilosofiese - en filosofies-antropologiese begronding}

Die mens is vryheid en openheid en daarmee saam is hy ongeborgenheid. Dit beteken dat elke mens die juiste verhouding moet vind tussen homself en die wêreld waarin hy lewe. Die mens ken geen vaste, aangebore verhouding tussen hom en sy wêreld nie. Hierdie juiste verhouding word vir hom ontwerp en déúr hom ontwerp en dit is ' $n$ lewenstaak wat nooit ten einde loop nie en nooit voltooi word nie.

Maar die mens leef ook nooit alleen nie. Hy is aangewys, deur sy aanvanklike hulpeloosheid, op grootword binne 'n besondere kultuur. Daarom is enige kultuur altyd die kultuur van mense en daarom is dit vanselfsprekend dat elke kultuur wesenlik die kenmerke moet dra van die mense wat dit bevolk.

Die kenmerke wat hier ter sprake kom, is die bogenoemde kenmerke van openheid en ongeborgenheid.

Omdat hierdie twee sake kenmerke is van elke mens, moet elke kultuur, sy dit nou die kultuur van 'n besondere volk, sy dit nou 'n breër kultuurtipe, hom verantwoord ten opsigte van twee baie belangrike sake. Hierdie twee sake is kennis van die mens se wêreld en sekuriteit.

Die mens het, op grond van sy openheid en sy ongeborgenheid, nood aan kennis en nood aan sekuriteit. Hy ís nie maar net in die wêreld nie, hy bewoon dit dinamies en moet dus daarvan kennis neem, móét dit probeer verklaar en móét teen die bedreigings en onsekerhede wat dit vir hom inhou, sekuriteit vind.

In 'n mitiese kultuur vervul die mite beide hierdie funksies. Die mite verskaf kennis deurdat dit dinge verklaar en dit verskaf sekuri- 
teit omdat dit die weë aantoon waardeur met die gode of die voorvaders gepraat kan word.

\section{Die aanvang van ' $n$ funksionele kultuur}

In die Westerse wêreld het die Christendom die mite vervang met 'n openbaring. Gedurende die Middeleeue het die Bybel gedien as bron van kennis én as bron van sekuriteit. As die Bybel nie kennis direk verskaf het nie, was dit ten minste gebruik as toetssteen vir kennis wat uit 'n ander bron gekom het.

Die Inkwisisie is as ' $t$ ware 'n ekstreme, maar tog 'n goeie, voorbeeld van hoe vas die kerk gestaan het by sy letterlike uitleg van die Bybel. Dit beteken ook dat die kerk daarby gestaan het dat geen vorm van kennis die letterlike interpretasie van die Bybel as verskaffer van kennis mog teenspreek nie.

In die figure van Copernicus, Kepler, Brahe, Galileo en uiteindelik Giordano Bruno, wat in die jaar 1600 op die brandstapel sterf, tref ons goeie voorbeelde aan van navorsers wat in mindere of meerdere mate met die kerk gebots het.

As mens die saak beskou teen die agtergrond van ons inleidende paragrawe, dan blyk dit dat Copernicus se rewolusie nie net ' $n$ rewolusie op die gebied van die astronomie was nie; Copernicus en sy medestanders het inderdaad 'n groot kulturele verandering ingelei.

Die Bybel het naamlik sy rol begin verloor as bron van wêreldkennis.

Die verandering wat ingetree het, was so onafwendbaar en so duidelik, dat die kerk stap vir stap toegegee het. Die voorwaarde was egter altyd dat alle bewerings klinkklaar gestaaf moes kon word.

Omdat Galileo nie die Copernikaanse teorie uit en uit kon bewys nie, is hy uiteindelik die stilswye opgelê.

Wat egter belangrik is, is die feit dat die wétenskap voortaan in die Westerse wêreld die kennisfunksie sou vervul, terwyl die Bybel die sekerheid vir die ongeborge mens sou verskaf.

Die openbaring het nou nie meer die dubbele rol vertolk wat deur die mite in die mitiese kultuur vertolk word nie, en drastiese herinterpretasie het nodig geword.

Die klem het dus wat die Bybel betref, verskuif vanaf die verhalende en die uiterlike na die prinsipiële. ('n Mens dink hier onwillekeurig aan Bultmann se program vir demitologisering.)

Wat moet ons nou eintlik leer uit díe stukkie wysgerige antropologie en kultuurfilosofie en uit die kort maar bekende verhaaltjie van Copernicus en die ander name wat ons hierbo genoem het?

Die belangrikste les is waarskynlik die feit dat die Bybel sy rol as kennisbron, dit wil sê bron van wêreldkennis, verloor het, binne die klimaat van ' $n$ kultuurverandering. Dit het gepaard gegaan met 'n 
nuwe verstaan van die wêreld waarin ons lewe, met verreikende gevolge vir die mensdom. Die mensdom het hom naamlik bevind op die vooraand van 'n funksionele kultuur wat nuwe horisonne op feitlik alle terreine sou open.

Die gebeure wat gelei het vanaf 1600 tot 1978 , was snelle gebeure, met 'n geweldige impak op die mens. Die veranderinge wat plaasgevind het, was in baie gevalle ingrypend en alhoewel dit nie vir almal so mag lyk nie, was die veranderinge wat die ontluikende fisika meegebring het wat die kerk betref ewe ingrypend. Op die aard dáárvan het ons egter reeds gewys.

Hoe verstaan die mens wat in 'n funksionele kultuur woon sy wêreld?

In watter soort wêreld word die mens van vandag grootgemaak? Hoe verstaan hy sy wêreld?

Die wetenskap maak dit moontlik vir die mens om sy wêreld te verklaar. Die wetenskap doen egter hierdie verklaring binne' $n$ uiters streng dissiplinêre struktuur. Slegs indien die wetenskaplike die grootste mate van presiese formulering, strukturering, meting, sintetisering en analise toepas, kan hy hoop op sukses. Die wetenskap stel egter, in samehang met bogenoemde faktore, ook ander eise.

Die mens is vanselfsprekend slegs in staat om die wêreld te verstaan in terme van die fundamentele kenmerke daarvan. Hierdie kenmerke is nie sigbare, voor die hand liggende kenmerke nie. Hulle word langsaam aan die werklikheid ontwortel en as natuurwette in die vorm van wiskundige formules uitgedruk.

Nou is dit baie noodsaaklik om te begryp dat vandag se synsverstaan of wêreldbeeld ' $n$ wêreldbeeld is wat deur die wetenskap gevorm is. Nog belangriker om te begryp is die feit dat vandag se mens feitlik sy hele wêreld begryp, verstaan en belewe in terme van wetenskaplik blootgelegde beginsels, begrippe en simbole.

Dit is wat ons verstaan onder 'n wetenskaplike wêreldbeeld.

Hierdie wêreldbeeld beteken ook dat die taal wat mense praat en die kriteria in terme waarvan evalueer word, die kenmerke daarvan dra.

Vandag se mens word opgevoed om strak, presies, bondig en logies te dink en te praat en hy word geleer om in terme van relevante kriteria te dink. Dis nie baie moeilik om te verstaan waarom dit noodsaaklik is om hom juis so op te voed nie.

Die omgewing waarin hy lewe, is een wat tot 'n baie hoë mate deur hom gekultiveer is. Verder word die omgewing spesifiek gekultiveer of ontwerp in terme van wetenskaplike beginsels. Hierdie mensgemaakte omgewing vertoon al die kenmerke van die wetenskap self.

Die produkte waardeur die omgewing bevolk word, vertoon 
naamlik die kenmerke van akkuraatheid, doeltreffendheid, bondigheid (ruimtelik klein van omvang), ensovoorts.

'n Verdere kenmerk van die moderne mens se omgewing is die feit dat dit 'n omgewing is wat uiters doeltreffend bestuur moet word. As dit nie gedoen word nie, dit wil sê as die bestuur daarvan verwaarloos of opgeskort sou word, word die omgewing onmiddellik vyandig teenoor die mens.

Dit is dus vanselfsprekend dat die mens vandag opgevoed word om verantwoordelik op te tree en spesifiek verantwoordelik op te tree binne die raamwerk van die funksionele omgewing waarin hy leef.

Die feit dat die mens opgevoed word met die oog op die doeltreffende bestuur van sy omgewing, is dus 'n oorlewingspoging, dit natuurlik gesien teen die agtergrond daarvan dat sy omgewing vyandig word as hy dit nie doeltreffend bestuur nie.

Die feit dat ons hier te maak het met oorlewing, verklaar waarom daar baie min twyfel bestaan oor die noodsaak van beroepsgerigte onderwys en al die ander moderne verskuiwings wat daarmee gepaard gaan.

In terme van ons inleidingsparagraaf word dit nou duidelik dat vandag se mens net bereik kan word indien hy aangespreek word binne die raamwerk van sy wêreldbeeld.

Die geboue en terreine waarin hy woon en werk en waaroor hy beweeg, is netjies, funksioneel en sindelik - nie te min lig nie en nie te veel geraas nie. Vir alles is daar' $n$ begrypbare, grondige, wetenskaplike en onomstootlike verklaring.

Die opvoeder van vandag staan voor die eis dat hy die omgewing waarin ons woon, moet verstaan en dat hy die wêreldbeeld van vandag se mens moet verstaan. Dit maak nie saak of hierdie opvoeder 'n instrukteur in die weermag, ' $n$ onderwyser, 'n predikant, 'n dosent by ' $n$ tegniese kollege, ' $n$ professor, of wat ookal is nie.

Die eis wat aan die opvoeder gestel word, is egter nie net ' $n$ teoretiese een nie. Daar is praktiese implikasies.

Die predikant moet begryp dat mooi, soet taal wat deurspek is van simbool, beeld en allegore, en dat woorde wat vaag en meersinnig is, nie goed genoeg is nie; die dosent moet begryp dat didaktiese beginsels sy werk moet onderlê; die didaktikus moet begryp dat die beginsels wat hy ontwerp, in harmonie moet wees met 'n funksionele wêreldbeeld!

Wie dit nie begryp nie, begryp nie die geskiedenis nie. Die geskiedenis van alle kulture leer ons dat niks in isolasie en bloot toevallig geskied nie. Elke kultuur dra sy eie klimaat of wesenlike aard, en in alle aspekte van elke kultuur sit hierdie wesenlike aard in een of ander vorm opgesluit. 
Wat in harmonie daarmee is, is verstaanbaar en aanvaarbaar, en wat nie is nie, hoort in 'n ander tyd - gewoonlik die verlede.

\section{Bronnelys}

1. Capek, M: The philosophical impact of contemporary physics, D van Nostrand Company, Inc, New York, 1961.

2. Dimer, A: Wass heisst wissenschaft? Verlag Anton Hain, Meisenheim am Glan, 1964.

3. Evans, J: Leven in de middeleeuwen, Uitgeversmaatschappij $\mathbf{W}$ de Haan $\mathbf{N}$, Leuven.

4. Hurd, D L en Kipling, J J (RED): The origin and growth of physical science vol I and II, Penguin Books Ltd, Pelican NR A534, 1964.

5. Janson, M: Probleme rondom die belydenis van die bestaan van God in die huidige tegnosentriese eeu, in sielkundebiblioteek 14, Mens en Tegniek, JL van Schaik Beperk, Pretoria, 1969.

6. Jevons, FR: Science observed, science as a social and intellectual activity, George Allen and Unwin Ltd, London, 1973.

7. Koestler, A: The sleepwalkers, The Danube Edition, Hutchinson of London, 1968.

8. Leff, G: Medieval thought - St Augustine to Ockham, Penguin Books Ltd. Harmondsworth, Middlesex, England, 1970.

9. Rait, R S: Life in the medieval university Cambridge, The University Press, 1931.

10. Roux, A S: Die Elektroniese kommunikasie van inligting - Enkele mensprobleme, in sielkundebiblioteek 14, Mens en Tegniek, J L van Schaik Beperk, Pretoria, 1969.

11. Toulmin, $\mathrm{S}$ en Goodfield, J: The fabric of the heavens, Hutchinson of London, 1961. 